\title{
Performance of Making Services to Establish Building (IMB) Tanah Siang Selatan District, Murung Raya
}

Dommy Joan Eka Dinata*, Budi Suryadi, Jamal Uddin

Master Program of Government Science, Lambung Mangkurat University, Banjarmasin, Indonesia

DOI: $10.36348 /$ sijlcj.2020.v03i06.001

| Received: 29.05.2020 | Accepted: 05.06.2020 | Published: 12.06.2020

*Corresponding author: Dommy Joan Eka Dinata

\section{Abstract}

Improving the quality of service is a necessity for public services. Specifically, the quality of IMB-making services, what factors contributed to the making of IMBs, and what efforts needed to be done to optimize the IMB-making services in the BPPT Murung Raya Regency. The focus of this study is the quality of IMB licensing services. The purpose of this study was to determine the quality of service for making IMB at BPPT Murung Raya Regency. This study uses qualitative research with a descriptive approach. Data collection techniques using interview techniques, observation and documentation, in the form of documents and archives relating to the quality of IMB services at BPPT Murung Raya Regency. The results showed that the BPPT Murung Raya regency in providing IMB licensing services had run well even though there were still some deficiencies encountered, such as infrastructure and human resources. The research concludes that the IMB service at the Murung Raya BPPT regency has been going well although there are still some things that are not optimal and need to be improved. Researchers suggest that the services provided by BPPT must be more professional, effective, efficient, and the deficiencies that need to be corrected to be optimal.

Keywords: Performance, Public Service Quality, Building Construction Permit.

Copyright @ 2020: This is an open-access article distributed under the terms of the Creative Commons Attribution license which permits unrestricted use, distribution, and reproduction in any medium for non-commercial use (NonCommercial, or CC-BY-NC) provided the original author and source are credited.

\section{Preliminary}

One background to the implementation of the Bureaucracy Reform is the quality of public services that do not meet the expectations of the community, in the sense that the level of public satisfaction is still low, marked by the many complaints against public service providers [1], both related to service procedures that still seem complicated, delays in administration, unreachable costs, and the attitude of service personnel who do not reflect the attitude of being a public servant. In-Law Number 32 the Year 2004 regarding Regional Government it has been explicitly mandated that to improve the welfare of the people, it will be pursued through 3 channels, namely improving public services, increasing the participation and empowerment of the community, and increasing competitiveness.

The District Government as a unit of regional government organization has a strategic position because it is at the forefront of dealing directly with people who have a variety of backgrounds, needs, and demands that are always changing and developing [2]. Through the Minister of Domestic Affairs Regulation No. 4 of 2010 concerning Guidelines for Integrated District Administrative Services (PATEN), which is then followed up with Decree of the Minister of Home Affairs No. 238-270 regarding Technical Guidelines for Integrated District Administration Services Guidelines, the government seeks to improve the quality of public services following public expectations as a customer to realize Good Local Government [3].

Geographical conditions in the form of distance between the customer's residence and the service location are too far away so that PATEN is expected to be a solution to make the sub-district as a community service center and to represent district-level SOPDs, especially those that provide one-stop integrated services (PTSP). As a service center, the subdistrict is expected to be able to provide services to the community proportionally based on the criteria and scale of the sub-district in the fields of licensing and non-licensing. Through Murung Raya District Regulations Number 18 the Year 2015 regarding Licensing and Non-Licensing Services Standards for Integrated Administrative Services in Sub-Districts in the Districts of Murung Raya, one of the licenses issued by the sub-district is the granting of one-story or multistory building permits with a maximum area of $70 \mathrm{~m}^{2}$. 
Law No. 28/2002 concerning Buildings Article 1 paragraph (1) states that buildings are physical forms of the results of construction work that are integrated with their domicile, partly or wholly on top and/or inland and/or water, which functions as a place humans carry out their activities, both for residential or residential, religious activities, business activities, social activities, culture, and special activities. Furthermore, it is said in paragraph (9) that the owner of a building is a person, legal entity, group of people, or association, which according to the law is valid as the owner of the building. In the sense that without written evidence a confession before the law regarding the object of the law, in this case, the building becomes invalid.

As if the low ability of the bureaucracy in responding to community needs and global demands led to a crisis of confidence in the public bureaucracy [4]. This makes the life of the community more difficult and passive to take the initiative, therefore the creation of the bureaucratic apparatus is very much needed in the effort to restore the people's living conditions. Empirical experience in the field shows that the implementation of services in the field of licensing is still very far in reality from what should be. This raises complaints about both from the citizens in handling applications for Building Permits which should also be reviewed from the bureaucrats who carry out the permit issuance process because of technical issues that disrupt the process.

In the administration and implementation procedures in the field for verification of Building Permit data, there are also various kinds of obstacles, based on the results of the examination of the Financial Management Agency of the Republic of Indonesia (BPK-RI) representative of Central Kalimantan in 2015 for operational district officials in terms of verifying the buildings submitted for permit issuance it is not permitted to make or budget for the making of an Official Travel Order (SPPD) while the basis for the provision of user fees is not yet determined by the Regional Government of Murung Raya Regency which results in fees for levies from the community being considered illegal. On the other hand, the levy obligation that must be paid by the sub-district to the Regional Revenue Service of Murung Raya Regency is one of the fees for building permits.

According to Dwiyanto [5], the performance evaluation of public bureaucracy is not enough to be done by using indicators attached to the bureaucracy, such as efficiency and effectiveness, but seen from indicators that are inherent to service users, such as service user satisfaction, accountability, and responsiveness. Performance appraisal form the service user side becomes very important because public bureaucracy also arises. After all, the goals and mission of public bureaucracy often not only have many stakeholders and have interests that often clash with each other causing the public bureaucracy to have difficulty in formulating a clear mission. This article aims to describe the performance of permit making in constructing Tanah Tanah Selatan Sub-district, Murung Raya Regency.

\section{RESEARCH METHODS}

The approach used in this study is qualitative. This approach was chosen because the researcher intends to obtain an in-depth description of the performance of the service of making a Building Permit (IMB) by Tanah Siang Selatan District Murung Raya District [6]. A qualitative approach is a process of research and understanding based on the methodology that investigates a social phenomenon and human problems. In this approach, the researcher makes a complex picture, examines detailed reports from the respondents' views, and conducts a study of the situation experienced. Qualitative methodology is a research procedure that produces descriptive data in the form of written and oral data from people and observed behavior [7].

The selection of research sites is based on the consideration of the suitability of the substance of the problem in this study and also the consideration of data entry both people, programs, structures, and interactions following the needs of in-depth description. The focus of research refers to five aspects; productivity, responsiveness, responsibility, and accountability. Data collection techniques carried out with three stages; 1) observations at the study site, namely the Murung Raya Regency PUPR Service Office, Tanah Siang Selatan District, and the Murung Raya Regency Building Permit service office, 2) an interview with the South Tanah Siang District Head, Murung Raya Regency; Head of Murung Raya Regency PUPR Service; Head of Murung Raya Regency DPMPTSP; Staff at the Tanah Siang Selatan Subdistrict Office of Murung Raya Regency relating to Building Permit services (IMB) which will be randomly selected, and people who have received services to make Building Permits (IMB) which were chosen accidentally 3 ) documentation as a complementary research data [8]. Data analysis techniques using the model of Miles and Huberman with three stages, namely; data reduction, data presentation in the form of description, and verification/data conclusions. Meanwhile, to achieve data saturation, data validity testing is done.

The data validity test conducted in this research is triangulation. Triangulation includes; sources, techniques, and time [9] and the community that has received services for making Building Permit (IMB) chosen accidentally 3) documentation as a supplementary research data [8]. Data analysis techniques using the model of Miles and Huberman with three stages, namely; data reduction, data presentation in the form of description, and 
verification/data conclusions. Meanwhile, to achieve data saturation, data validity testing is done. The data validity test conducted in this research is triangulation. Triangulation includes; sources, techniques, and time [9] and the community that has received services for making Building Permit (IMB) chosen accidentally 3) documentation as a supplementary research data [8]. Data analysis techniques using the model of Miles and Huberman with three stages, namely; data reduction, data presentation in the form of description, and verification/data conclusions. Meanwhile, to achieve data saturation, data validity testing is done. The data validity test conducted in this research is triangulation. Triangulation includes; sources, techniques, and time [9]. Meanwhile, to achieve data saturation, data validity testing is done. The data validity test conducted in this research is triangulation. Triangulation includes; sources, techniques, and time [9]. Meanwhile, to achieve data saturation, data validity testing is done. The data validity test conducted in this research is triangulation. Triangulation includes; sources, techniques, and time [9].

\section{RESULTS AND DISCUSSION}

Communication in the Implementation of Building Permit Service Policy (IMB) in Murung Raya Regency communication has been effectively established within the scope of implementing the Building Permit (IMB) service program as the decisionmakers know what they are going to do so that the tasks and responsibilities they will do can go well. Whereas communication between the program implementers and the target groups including the people of Murung Raya Regency in general and in particular the IMB applicant is still ineffective despite the socialization of regulations regarding Building Permit in Murung Raya Regency.

Communication is a human activity to convey its thoughts and feelings, hopes, or experiences to others [15]. The communication factor is considered as a very important factor because it is a bridge between the community and the government in implementing policies. So it can be seen whether the implementation of the policy runs effectively and efficiently without being harmed. Effective implementation occurs when policymakers and implementors know what is being done, and that can only be obtained through good communication.

Communication is one of the important variables that affect the performance of public services, communication is crucial in the success of achieving the objectives of public policy implementation [10]. The communication factor is very influential in the acceptance of the policy by the target group so that the quality of communication influences the effectiveness of public service performance. Thus, the dissemination of policy content through a good communication process affects policy implementation. The communication media used to disseminate policy content to the target group is very important.

The function of coordination and communication between organizations can be seen as a part of the glue, alignment, or integration of the work implementation of each work unit so that it becomes a unified work mechanism that is compact and directed to a goal and target previously set [11]. Besides that, through communication, various problems and obstacles in providing services to the community can be identified, and then solutions can be formulated. Thus, the prospect of effective policy implementation is largely determined by the communication of policy implementers and is accurate and consistent. Policy communication has several dimensions, including the dimensions of transformation, clarity, and consistency. The transmission dimension requires that public policies are conveyed not only to policy implementers.

Therefore, the communication dimension includes policy transformation, clarity, and consistency. The dimension of transformation requires that public policy can be transformed to implementers, target groups, and other parties related to policy (Ruslan, Public Relations Management and Media Communication). The clarity dimension requires that policies transmitted to implementers, target groups, and other parties that have a direct or indirect interest in the policy can be accepted so that they are aware of the aims, objectives and targets, and the substance of the public policy. If it is not clear, they do not know what should be delivered and implemented so that objectives and policies can be achieved effectively and efficiently.

In line with what was stated by Van Horn and Van Mater [12] that for policies to be implemented properly, what is the standard goal must be understood by individuals? Responsible for the achievement of standards and policy objectives, therefore standards and objectives must be communicated to the implementers. Communication in the context of delivering information to policy implementers about what are the standards and objectives must be consistent and uniform from various sources of information. Prospects for effective policy implementation are largely determined by communication to policy implementers accurately and consistently [12].

If there is no clarity and consistency and uniformity towards a standard and policy objective, then what becomes the standard and policy objective is difficult to achieve. With this clarity, policy implementers can find out what is expected of them and what must be done. In a public organization, local government, for example, communication is often a difficult and complex process. The process of transferring news down within the organization or from one organization to another, and other communicators, often experiences both intentional and unintended 
interference. If different communication sources provide different interpretations of a standard and purpose, or the same source of information provides conflicting interpretations,

The prerequisite for running an organization is ownership of resources. Edward III categorizes organizational resources consisting of: "Staff, information, authority, facilities; building, equipment, land, and supplies" [12]. Edward III argued that these resources could be measured from the aspect of adequacy in which implied suitability and clarity. This is in line with what Edward III stated that resources are important in implementing good policies. The indicators used to see the extent to which resources influence policy implementation consists of:
a) Staff
b) Information
c) Authority
d) Facilities [10]

The success of the policy implementation process is highly dependent on the ability to utilize available resources. Humans are the most important resource in determining a successful implementation process. Certain stages of the entire implementation process require politically determining human resources. But when the competence and capability of these resources are zero, then the performance of public policies is very difficult to expect. Implementation of policies needs support from human resources and nonhuman resources support [13]. In addition to human resources, other resources should also be taken into account in implementing the IMB policy in Barito Raya Regency. Like financial resources and time resources, because when competent and compatible human resources are available, but not supported by financial resources and facilities and infrastructure in implementing policies, then it will become a complicated issue to realize what is intended to be the purpose of the IMB policy itself. Characteristics of policies are the ability of policies to structure the implementation process, one of which includes the amount of financial resource allocation to the policy [10].

Furthermore, Van Mater and Van Horn [12] suggest that policy resources are no less important than communication. These policy resources must also be available to facilitate the administration of the implementation of a policy. These resources consist of funds or other incentives that can facilitate the implementation of a policy. Lack of or limited funds or other incentives in policy implementation is a major contribution to the failure of policy implementation". In the opinion of Van Metter and Van Horn in Agustino [10]: "the attitude of acceptance or rejection of policy implementing agents greatly influences the success or failure of the implementation of public policies. This is very possible because the policies implemented are not the result of the formulation of residents who are well aware of the problems and problems they feel. But public policy is usually top-down which is very possible decision-makers do not know even unable to touch the needs, desires or problems that must be resolved".

The widespread and in-depth acceptance of policy standards and objectives among those responsible for implementing the policy is a great potential for successful policy implementation. In the end, the intensity of the disposition of the implementers can influence the implementers (performance) of the policy. The lack or limited intensity of this disposition causes the failure of policy implementation [3]. The results of the study showed that the BPPT Service, which had authority in matters of bureaucracy while the implementation of services was taken over by the District Government of Tanah Siang Selatan as the executor of the Building Permit (IMB) service, knew, understood and understood the main tasks, functions, and responsibilities of each, both individually and institutionally. Besides, the District Government of Tanah Siang Selatan is also actively conducting supervision and control of buildings that violate Building Permit (IMB). The performance of complex policy services requires the cooperation of many parties. When the bureaucratic structure is not conducive to the implementation of a policy, this will cause ineffectiveness and hinder the implementation of the policy. Based on the explanation above, then understanding the bureaucratic structure is a fundamental factor for assessing the implementation of public policies. When the bureaucratic structure is not conducive to the implementation of a policy, this will cause ineffectiveness and hinder the implementation of the policy.

According to Edwards III, there are two main characteristics of bureaucracy namely: "Standard Operation Procedure (SOP) and Fragmentation". According to Edward III, 2 (fruit) main characteristics of the bureaucratic structure are standard work procedures (SOP $=$ Standard Operating Procedures) and fragmentation [12]. Standard Operating Procedures (SOP) were developed as an internal response to the limited time and resources of implementers and the desire for uniformity in the workings of complex and widespread organizations. SOP that are routinely designed for typical situations in the past might inhibit changes in policy because they are not appropriate to the new situation or program. SOP is very likely to hinder the implementation of new policies that require new ways of working or new types of personnel to implement policies. The greater the policy requires changes in the routine way of an organization, the greater the probability of SOP impeding implementation. 
Fragmentation comes mainly from pressures from outside bureaucratic units, such as legislative committees, interest groups, executive officials, the State constitution, and the nature of policies that affect public bureaucratic organizations. Fragmentation is the spread of responsibility towards a policy area among several organizational units. "Fragmentation of the dispersion of responsibility for a policy area among several organizational units" [14]. The more actors and agencies involved in a particular policy and the more interrelated their decisions are, the less likely the success of the implementation. Edward stated that in general, the more coordination needed to implement a policy, the less chance of success [14]. In the performance of the service policy apparatus, Building Permit in Murung Raya Regency SOP is available so that employees or implementers of IMB service policies carry out routine activities every day following established standards. In terms of fragmentation in the form of efforts to spread the responsibility of the activities and activities of employees among several units where the BPPT Office's Renja has clearly defined the duties and functions of each field. In the process of the performance of the apparatus of the BPPT Office of Building Permit (IMB) service in Murung Raya Regency, it is seen from four indicators, namely: communication, resources, disposition, and bureaucracy.

Resources, in this case, human resources, financial resources, and equipment resources. In human resources, it is still lacking and limited. There is no accuracy and appropriateness between the number of staff needed and the expertise possessed following the job assignments handled. Financial resources are already quite effective with the existence of programs and activities on Building Permit (IMB). Equipment resources are still limited to support the operationalization of the implementation of the Building Permit (IMB) service policy. Disposition and bureaucracy are considered effective. The IMB service policy implementors in Murung Raya Regency already know what they have to do and implement the policy following their respective duties and functions, and they have the will to implement the policy. The BPPT Office, which has the authority in terms of implementing the Building Permit (IMB) bureaucracy, already knows, understands, and understands the main tasks, functions, and responsibilities of each, both individually and institutionally.

Starting from the opinion of Edward III, stated that the model or approach to policy implementation, obstacles often faced in the implementation of public policy include resources. The main resource in policy performance is staff or employees (street-level bureaucrats) $[14,10]$. Failures that often occur in policy performance, one of which is caused by staff/employees who are inadequate, insufficient, or incompetent in their fields. Increasing the number of staff and implementors alone is not enough to solve the problem of policy implementation, but it requires sufficient staff with the necessary expertise and capabilities (competent and capable) in improving employee performance. In addition to resources, information, and communication are also factors that become obstacles in the process of improving service performance. In implementing policies, information takes two forms: first, information relating to implementing policies. Second, information about the compliance data from the implementers of the rules and regulations set by the government. Communications received by policy implementers (street-level-bureaucrats) must be clear and not confusing or ambiguous [13].

According to Cheema and Rondinelli [13], there are four groups of variables that affect the performance and impact of a program, namely: 1). Environmental conditions; 2). Relations between organizations; 3). Organizational resources for program implementation; and 4). Characteristics and capabilities of the implementing agent. The policy has a variety of views in formulating factors that affect the performance of the apparatus. In the variation of these views, it can be concluded that performance is a very complex process because many factors can influence the performance of the apparatus. Based on the results of the identification of the performance process of Building Permit (IMB) services in Murung Raya Regency, it can be seen that the factors which become obstacles in the process of IMB service performance are as follows:

1. Limited resources, both from human resources, namely the Building Permit (IMB) service staff, and financial resources, namely the minimal facilities.

2. Buildings that are not following spatial patterns so that the buildings are not well ordered and buildings that violate the Border Line (GSB).

\section{CONCLUSION}

The success of the policy implementation process is highly dependent on the ability to utilize available resources. Humans are the most important resource in determining a successful implementation process. Certain stages of the entire implementation process require politically determining human resources. But when the competence and capability of these resources are zero, then the performance of public policies is very difficult to expect. Performance is an achievement or work results in activities or activities or programs that have been planned to achieve the goals and objectives set by an organization and implemented within a certain period that is influenced by several factors. Performance evaluation of public bureaucracy is not enough to be done by using indicators that are attached to the bureaucracy, such as efficiency and effectiveness, but also must be seen from indicators that are inherent to service users, such as service user 
satisfaction, accountability, and responsiveness. Performance appraisal form the service user side becomes very important because public bureaucracy also arises because of the goals and mission of the public bureaucracy.

\section{REFERENCES}

1. Effendi, S. (2005). Reformasi Birokrasi. Jakarta: Lembaga Administrasi Negara.

2. Sutrisno, H. (1998). Mewujudkan Good Governance melalui Pelayanan Publik. Yogyakarta: Gajah Mada University Press.

3. Hardiyansyah. (2011). Kualitas Pelayanan Publik Konsep, Dimensi, Indikator dan. Implementasinya. Yogyakarta: Gava Media.

4. Abdul, C. D. (2015). Pelayanan Publik Tingkat Desa. Yogyakarta: Interpena.

5. Dwiyanto, A. (Ed.). (2006). Reformasi birokrasi publik di Indonesia. Gadjah Mada University Press.

6. Sugiyono. (2016). Memahami Penelitian Kualitatif. Bandung: Alfabeta.
7. Gunawan, I. (2014). Metode Penelitian Kualitatif Teori dan Praktik. Jakarta: Bumi Aksara.

8. Saebani, A. D. (2009). Metodologi Penelitian Kualitatif. Pustaka Setia: Bandung.

9. Iskandar. (2008). Metodologi Penelitian Pendidikan dan Sosial (Kuantitatif dan. Kualitatif). Jakarta: GP Press.

10. Agustino, L. (2006). Politik dan Kebijakan publik. Bandung: AIPI.

11. Ardianto, E. (2006). Public relations Suatu Pengantar Praktis. Bandung: Bumi Quraisy.

12. Widodo, J. (2006). Membangun Birokrasi Berbasis Kinerja. Jakarta: Bayumedia Publishing.

13. Subarsono, A. (2011). Analisis kebijakan Publik: Konsep. Teori dan Aplikasi. Yogyakarta: Pustaka Pelajar.

14. Edward III, G. C. (1980). Implementing Public Policy. Washington DC: Congressional Quarterly Press.

15. Mulyana, D. (2007). Ilmu Komunikasi Suatu Pengantar. Bandung: Rosdakarya. 